\section{ANALISIS IMPLIKASI KEBIJAKAN DIVIDEN TERHADAP PERTUMBUHAN PERUSAHAAN DAN KINERJA SAHAM}

Studi kasus pada PT Mitra Pinasthika Mustika Tbk yang Terdaftar di Bursa Efek Indonesia

\author{
Andre, Annaria Magdalena dan Ani Mekaniwati \\ Program Studi Manajemen, Sekolah Tinggi Ilmu Ekonomi Kesatuan \\ Bogor, Indonesia \\ Email :lemlit@stiekesatuan.ac.id
}

Dividend policy, company's growth, share performance, earning per share, share price.

\section{3}

This research was conducted using financial reports from companies engaged in retail distribution sector during the periods of 2013-2016 using financial ratios analysis. These ratios described how profitability, assets management and company's equity are affecting the dividend policy. We can conclude that dividend policy has major impact on the company's growth and stock performance.

The results show that a slight decrease in the stock price will also cause a decrease in the profit and eventually causing decrease to the earning per share. The dividend per share experiences an increase because these companies still intent to pay the dividend among their share holders to maintain share price. Share price declines due to the interest rate policies of Bank Indonesia and the value of export import. These companies have run proper dividend policies by maintaining the growth and company value, seen from the increasing portion of retained earnings and the portion of dividend payment. Thus the decreasing price of share is mostly caused by external factors.

Keywords : Dividend policy, company's growth, share performance, earning per share, share price.

\section{PENDAHULUAN}

Perkembangan distribusi ritel, khususnya distribusi suku cadang kendaraan telah mengalami kemajuan yang sangat pesat, seiring dengan perkembangan teknologi modern saat ini telah menjadi bisnis global dan Indonesia tidak terhindarkan dari serbuan ritel asing, Dengan perkembangan ekonomi yang sangat pesat, tentu akan menimbulkan persaingan ketat antara perusahaan sejenis. Persaingan ini tentu saja tidak berpusat pada penjualan saja tapi juga menyangkut dengan hal lain seperti kinerja keuangan dan kinerja saham.

PT. Mitra Pinasthika Mustika Tbk. (MPMX) adalah perusahaan yang bergerak dalam bidang distribusi dan ritel untuk sepeda motor Honda, manufaktur dan distribusi suku cadang mobil, seperti minyak pelumas, layanan mobil (seperti sewa mobil dan jasa keuangan auto terkait pembiayaan konsumen dan asuransi produk - produk), jasa transportasi yang berkualitas tinggi serta pelayanan terbaik demi kepuasan konsumen. PT. Mitra Pinasthika Mustika, masuk dalam sektor: trade, services \& investment, Sub Sektor : Wholesale (Durable \& Non Durable Goods).

PT MPMX menarik untuk menjadi objek penelitian karena di tengah perkembangan bisnis distribusi dan ritel yang meningkat sangat pesat dengan persaingan yang semakin
Submitted: JANUARI 2019

Accepted: APRIL 2019

\footnotetext{
JIMKES

Jurnal Ilmiah Manajemen Kesatuan Vol. 7 No.1, April 2019 pg. $153-161$ pg. $153-16$ ISSN $2337-7860$
} 
Dividend

policy, company's growth, share performance, earning per share, share price. ketat, namun perusahaan ini justru menunjukkan pergerakan yang menurun bahkan penurunan kinerja keuangan perusahaan.

Analisis laporan keuangan merupakan proses evaluasi kinerja perusahaan terkait dengan posisi keuangan dan hasil yang telah dicapai perusahaan dan dapat digunakan untuk memprediksi kinerja perusahaan di masa mendatang.

\section{TINJAUAN PUSTAKA}

\section{Profitabilitas}

Husnan (2001) mengatakan bahwa profitabilitas merupakan kemampuan suatu perusahaan dalam menghasilkan keuntungan (profit) pada tingkat penjualan, aset, dan modal saham tertentu. Sedangkan Menurut Michelle \& Megawati (2005) Profitabilitas adalah kemampuan perusahaan menghasilkan laba (profit) yang akan menjadi dasar pembagian dividen perusahaan.

Gibson (2001) mendefinisikan profitabilitas adalah kemampuan suatu perusahaan untuk meningkatkan laba perusahaan, prof itabilitas ini diukur dengan membandingkan laba yang diperoleh perusahaan dengan sejumlah perkiraan yang menjadi tolak ukur keberhasilan perusahaan seperti aktiva perusahaan, penjualan dan investasi. Sehingga dapat diketahui efektivitas pengelolaan keuangan dan aktiva oleh perusahaan.

Rasio profitabilitas merupakan rasio untuk menilai kemampuan perusahaan dalam mencari keuntungan. Rasio ini juga memberikan ukuran tingkat efektivitas manajemen suatu perusahaan. Hal ini ditunjukan oleh laba yang dihasilkan dari penjualan dan pendapatan investasi (Kasmir, 2008).

\section{Dividen}

Menurut Lawrence J. Gitman (2006: 509) deviden is "A source of cash flow to stakeholder and provide information about firm's current and future performance.

Berikut ini adalah jenis-jenis deviden menurut Eugene $\mathrm{F}$ Bringham and Joel $\mathrm{F}$ Houston (2006: 95)

1) Cash Dividend

2) Stock Dividend

3) Property Dividend

4) Script Dividend

5) Liquidating Dividend

6) Dividen Saham Pecahan

\section{Pertumbuhan Laba}

Artur J.Keown $(2005,2)$ mengemukakan pertumbuhan laba sebagai : A Financial manager could easly increase current profits by eliminating reasearch and development expenditures and cutting don't on routine maintenance. In the short run, this might result in increased profits, but this clearly is not in the best long run interest of the firm.

Menurut Stephen A.Ross, Randholp W. Westerfield Bradford D. Jordan $(2009,130)$ menjelaskan bahwa : "Pertumbuhan merupakan satu sarana yang memudahkan dalam hal rangkuman berbagai aspek kebijakan keuangan dan investasi sebuah perusahaan". 


$$
\begin{aligned}
& \text { Pertumbuhan laba }=\frac{l a b a_{t}-l a b a_{t-1}}{l a b a_{t-1}} \times 100 \% \\
& \text { Keterangan : } \mathrm{t} 0=\text { Laba pada tahun berjalan } \\
& \text { t- } 1=\text { Laba pada tahun sebelumnya }
\end{aligned}
$$

\section{Kinerja Saham}

Saham adalah surat tanda bukti kepemilikan pada suatu perusahaan yang go public. Pengertian saham lebih lengkap diartikan sebagai sertifikat yang menunjukkan bukti kepemilikan suatu perusahaan dan pemegang saham memiliki hak klaim atas penghasilan dan aktiva perusahaan. Saham dibedakan menjadi dua jenis yaitu : saham biasa dan saham Preferen.

\section{Nilai Buku (Book Value)}

Book Value atau Nilai Buku adalah nilai sebuah aset atau kelompok aset dikurangi dengan sejumlah penyusutan nilai yang dibebankan selama umur penggunaan aset tersebut. Nilai buku suatu aset dalam periode tertentu bisa berbeda antara satu perusahaan dengan perusahaan lainnya. Hal ini terjadi karena nilai buku suatu aset di pengaruhi oleh metode penyusutan yang digunakan oleh perusahaan tersebut.

Nilai buku saham atau Book Value Per Share dihitung dengan rumus :

$$
P B V=\frac{\text { Total Ekuitas }}{\text { Jumlah Saham yang Beredar }}
$$

\section{Pasar (Market Value)}

Nilai pasar (market value) adalah harga saham yang terjadi di pasar pada periode tertentu oleh pelaku pasar. Market value merupakan rata-rata harga saham selama satu tahun dikalikan dengan jumlah saham beredar per akhir tahun. Semakin banyak jumlah saham yang beredar dan semakin tingginya harga saham menunjukan semakin besar ukuran sebuah perusahaan.

$$
\text { Nilai Pasar }=\text { Rata }- \text { Rata Harga Saham } \times \text { Jumlah Saham Beredar }
$$

\section{Manajemen Aset}

Manajemen adalah penggunaan dan koordinasi secara efektif atas sumber daya seperti modal, gedung,bahan, dan SDM untuk mewujudkan tujuan dengan cara yang paling efisien. Sedangkan aset berasal dari istilah asset yang dalam bahasa indonesia dikenal dengan istilah " kekayaan. Aset berdasarkan perspektif ekonomi diartikan sebagai berikut : aset adalah segala sesuatu yang memiliki nilai ekonomi yang dapat dimiliki baik oleh individu, perusahaan, maupun dimiliki pemerintaah yang dapat dinilai secara finansial.

\section{Rasio Likuiditas}

Menurut Fred Weston dikutip dari Kasmir (2008:129): menyatakan rasio likuiditas adalah rasio yang menggambarkan kemampuan perusahaan dalam memenuhi kewajiban hutang jangka pendek dengan menggunakan aktiva lancar.

\section{Pendanaan}

Dana yang ada pada perusahaan, baik yang bersumber dari dalam perusahaan maupun dari luar perusahaan harus digunakan sebaik mungkin. Hal ini bertujuan agar 
Dividend

policy, company's growth, share performance, earning per share, share price. nilai perusahaan semakin meningkat pada masa yang akan datang. Dana itu dapat digunakan untuk hal-hal berikut:

1) Penanaman modal jangka pendek.

2) Penanaman modal jangka panjang.

\section{METODE PENELITIAN}

Metode yang digunakan dalam penelitian ini adalah metode deskriptif, kuantitatif, yaitu metode studi kepustakaan dengan mengambil data-data yang diperlukan. Metode ini digunakan dengan tujuan untuk mengetahui analisis implikasi kebijakan dividen terhadap pertumbuhan perusahaan dan kinerja saham. Data yang digunakan, berdasarkan suatu riset, sehingga mendapatkan simpulan yang tepat.

Metode analisis yang digunakan peneliti adalah analisis non statistik yaitu membandingkan antara hasil riset dengan teori yang dilakukan terhadap data tersebut menggunakan sebuah grafik, apakah hasilnya positif dan signifikan atau malah sebaliknya.

a. Analisis Common Size

b. Analisa Trend

c. Analisis Rasio Keuangan

d. Analisis SWOT

\section{HASIL DAN PEMBAHASAN}

Perusahaan ini merupakan perusahaan distribusi ritel yang bergerak dalam bidang distribusi dan ritel untuk sepeda motor Honda, manufaktur dan distribusi suku cadang mobil seperti minyak pelumas, layanan mobil seperti sewa mobil dan jasa keuangan auto terkait seperti pembiayaan konsumen dan asuransi produk - produk dan jasa transportasi yang berkualitas tinggi serta pelayanan terbaik demi kepuasan konsumen yang sudah lama berjalan di sektor industri.

Analisis bisnis perusahaan menurut analisis SWOT, perusahaan ini memiliki kekuatan, peluang, kelemahan, dan ancaman. Dan dari semua variabel SWOT yang disajikan perusahaan memiliki cara untuk mengatasi seluruh ancaman dan kelemahan melalui peluang dan kekuatan yang perusahaan. Dan semua kelemahan dan ancaman itu bisa diatasi dengan perusahaan dengan cara perusahaan sendiri.

\section{a. Rasio Profitabilitas}

Menurut penjualan perusahaan dari tahun 2013 sampai tahun 2016 memilik tren yang lebih baik di bandingkan dengan rata-rata industri perusahaan yang berada di sub sektor yang sama. Kenaikan ini terbukti dari hasil perusahaan yang mampu mempromosikan produk dan layanan yang di keluarkan perusahaan sehingga pangsa pasar perusahaan memiliki pangsa pasar yang baik di mata masyarakat sehingga pangsa pasarnya sangat bagus di pasaran.

Menurut penjualan dari tahun 2013 sampai tahun 2016 memiliki tren yang turun dibandingkan dengan rata-rata industri. Hal ini menunjukan karena nilai penjualan dan harga pokok penjualan yang tinggi menyebabkan mengalami penurunan, karena penjualan yang tinggi ini terlalu beresiko dengan biaya operasionalnya yang dilakukan 
ekspor dalam luar negeri. Seharusnya perusahaan memiliki nilai harga pokok penjualan lebih kecil agar memiliki laba yang baik.

Menurut beban operasional terhadap penjualan dari tahun 2013 sampai tahun 2016 memiliki tren yang naik dan berada di atas rata-rata industri, perusahaan memiliki beban operasi yang besar dari tahun 2013 ke tahun 2016. Artinya perusahaan sangat tidak efektif dalam menekan biaya operasi sehingga akan berpengaruh dengan laba yang di dapat, biaya-biaya yang naik ini juga disebabkan karena industri dalam perusahaan melakukan ekspor ke luar negeri. Karena seharusnya perusahaan yang ingin memiliki laba yang baik harus bisa menekan biaya dalam produksi agar bisa menunjang laba yang di dapat perusahaan.

Menurut Net Profit Margin dari tahun 2013 sampai tahun 2016 memiliki tren yang menurun jika di bandingkan dengan rata-rata industri. Penurunan ini disebabkan karena perusahaan memiliki pembengkakan dalam biaya-biaya operasionalnya, biaya-biaya yang meningkat ini disebabkan karena kurs rupiah yang menguat terhadap dollar, tingkat inflasi karena penjualan perusahaan lebih banyak ekspor dalam luar negeri sehingga laba yang di dapat sangat sedikit bagi perusahaan.

Menurut Gross Profit Margin dari tahun 2013 sampai tahun 2016 memiliki tren yang menurun jika di bandingkan dengan rata-rata industri. Kenaikan margin laba kotor pada perusahaan belum efisien, walaupun tren perusahaan meningkat tetapi di dalam perusahaan masih memiliki biaya-biaya yang tinggi juga. Hal ini juga diakibatkan perusahaan belum bisa menekankan biaya-biaya yang tinggi sehingga labanya kecil.

Menurut Operating Profit Margin dari tahun 2013 sampai tahun 2016 memiliki tren yang menurun dibandingkan dengan rata-rata industri. Hal ini menunjukan bahwa laba usaha perusahaan menurun karena masih memiliki biaya-biaya operasional yang tinggi dalam melakukan ekspor ke luar negeri sehingga penjualan yang dilakukan perusahaan terlalu beresiko dan laba yang di peroleh oleh perusahaan sedikit di setiap tahunnya.

Menurut ROA pada tahun 2013 sampai tahun 2016 mengalami tren yang menurun. Artinya penurunan sumber daya yang dimiliki perusahaan belum mampu memaksimalkannya menjadi laba bersih. Hal ini berarti dengan aset-aset yang dimiliki oleh perusahaan, perusahaan belum mampu memanfaatkan aset asetnya dengan baik sehingga belum bisa menghasilkan keuntungan bagi perusahaan.

Menurut Return On Equity dari tahun 2013 sampai tahun 2016 memiliki tren yang menurun jika dibandingkan dengan rata-rata industri. Penurunan ini karena perusahaan tidak efisien dalam menggunakan modal investor yang ada untuk meningkatkan pendapatan perusahaan. sehingga perusahaan belum mampu memuaskan kepentingan pemegang saham dan para investor belum berani menanamkan modal untuk perusahaan yang akan berdampak pada penurunan return on equity.

\section{b. Rasio Aktivitas}

Menurut Current Asset Turnover dari tahun 2013 sampai tahun 2016 mengalami tren yang menurun. Artinya bisa jadi disebabkan oleh investasi pada aset lancar yang berlebihan apabila dibandingkan dengan nilai output yang akan diperoleh, sehingga perusahaan tidak mampu memanfaatkan aset-aset lancarnya untuk meningkatkan pendapatan perusahaan. penurunan ini berpengaruh dalam aset lancar yang dimiliki perusahaan tidak cepat berputar untuk meraih laba dan menunjukan tidak efisien dalam penggunaan keseluruhan aset untuk mendapatkan pendapatan.

Menurut Fixed Asset Turnover dari tahun 2013 sampai tahun 2016 mengalami tren yang menurun yang sama dengan rata-rata industri. Penurunan ini menunjukan bahwa

\author{
Dividend \\ policy, \\ company's \\ growth, share \\ performance, \\ earning per \\ share, share \\ price.
}


Dividend

policy, company's growth, share performance, earning per share, share price.

\section{8}

perusahaan tidak mampu memanfaatkan aset-aset tetapnya untuk menghasilkan produk perusahaan dalam jumlah besar sehingga berdampak pada laba perusahaan, sehingga perusahaan tidak efektif dalam menggunakan aset yang ada di perusahaan dan berpengaruh terhadap laba yang menurun.

\section{c. Rasio Likuiditas}

Menurut rasio lancar dari tahun 2013 sampai tahun 2016 memiliki tren yang menaik yang sama dengan tren rata-rata industri. Artinya walaupun tren perusahaan meningkat tetapi dalam manajemen aktiva lancarnya buruk, karena banyak persediaan yang belum terjual dan ada piutang yang belum terbayarkan dan angka rasio lancar perusahaan belum mencapai 1 sehingga perusahaan belum bisa menutupi kewajiban utang jangka pendek dan belum bisa membayar utang lancarnya dengan menggunakan aktiva lancar perusahaan.

Menurut Cash Ratio dari tahun 2013 sampai 2016 memiliki tren yang meningkat. Kenaikan tren ini tidak terlalu signifikan. Artinya kas perusahaan meskipun nilainya kecil tapi mampu membayar hutang jangka pendeknya dengan kas, makanya cash ratio perusahaan ini di bawah 1, karena kas yang kecil tapi perusahaan ini sedang berupaya untuk meningkatkan lagi kasnya sehingga bisa di atas 1. Sehingga perusahaan semakin mudah dalam membayar utang jangka pendeknya dengan kas yang dimiliki tapi perusahaan ini belum karena di bawah satu sehingga belum efektif.

Menurut rasio cepat dari tahun 2013 sampai tahun 2016 memiliki tren yang meningkat. Karena komponen persediaan dianggap tidak dengan mudah dapat digunakan untuk memenuhi kewajiban yang segera jatuh tempo artinya bahwa persediaan tidak dapat diuangkan itu karena harus nunggu dari hasil penjualan. Semakin kecil rasio semakin tidak baik juga posisi keuangan perusahaan karena akan berakibat perusahaan akan sulit dalam membayarkan kewajibannya lancarnya dalam waktu singkat.

\section{d. Rasio Solvabilitas}

Menurut Debt Asset Ratio dari tahun 2013 sampai tahun 2016 memiliki tren yang naik jika dibandingkan dengan rata-rata industri. Walaupun tren perusahaan meningkat tetapi hutang perusahaan tinggi disetiap tahun namun bukan berarti perusahaan itu tidak baik, manajemen perusahaan dapat mengoptimalkan permodalan yang berasal dari hutang yang digunakan untuk penambahan aset dengan tujuan untuk meningkatkan kualitas produk dan kapasitas produk, dengan aset yang semakin baik perusahaan dapat memanfaatkan permodalan hutang dengan baik.

Menurut Debt Equity Ratio dari tahun 2013 sampai di tahun 2016 memiliki tren yang naik jika dibandingkan dengan rata-rata industri. tren perusahaan meningkat karena semakin besar nilai DER akan memperbesar tanggungan perusahaan. DER yang tinggi mempunyai dampak buruk terhadap kinerja perusahaan, karena dengan tingkat utang yang semakin tinggi berarti beban bunga perusahaan akan semakin besar dan akan mengurangi keuntungan. Dengan tingkat utang yang tinggi dan dibebankan kepada pemegang saham, tentu akan meningkatkan risiko investasi kepada para pemegang saham.

\section{e. Analisis Kebijakan Dividen}

Menurut Earning Per Share dari tahun 2013 sampai tahun 2016 memiliki tren yang menurun jika di bandingkan dengan rata-rata industri. Tren yang menurun ini menandakan bahwa perusahaan tersebut belum berhasil meningkatkan kemakmuran 
investor dan perubahan suku tabungan, inflasi, nilai tukar rupiah menurun juga. Hal ini menunjukan bahwa perusahaan belum mendorong investor untuk menambah jumlah modal yang ditanamkan pada saham perusahaan dan jika EPS menurun maka pasar akan merespon negatif dengan diikuti penurunan harga saham.

Menurut Price Earning Ratio dari tahun 2013 sampai tahun 2016 memiliki tren yang naik jika dibandingkan dengan tren rata-rata industri. walaupun tren PER meningkat tetapi harga saham perusahaan mengalami penurunan dikarenakan tingkat suku bunga yang tinggi, inflasi, nilai tukar rupiah yang menurun sehingga penurunan ini berdampak pada potensi keuntungan perusahaan hingga pada akhirnya juga akan mempengaruhi harga saham perusahaan menurun.

Menurut Dividen per share dari tahun 2013 sampai tahun 2016 memiliki tren yang meningkat di bawah rata-rata industri. Hal ini menunjukan bahwa tren yang meningkat mencerminkan perusahaan memiliki prospek yang baik karena dapat membayarkan DPS dalam jumlah yang tinggi. Dan menarik investor untuk membeli saham perusahaan tersebut dengan banyaknya saham yang dibeli mengakibatkan harga saham perusahaan naik, tetapi di sini harga saham perusahaan mengalami penurunan yang disebabkan tingkat suku bunga perusahaan menurun, inflasi, dan nilai tukar rupiah terhadap dollar juga menurun.

Menurut tren pertumbuhan perusahaan dari tahun 2013 sampai tahun 2016 memiliki tren yang kurang begitu besar. Dan jika di lihat dari laba di tahan perusahaan memiliki tren yang naik. Artinya perusahaan ini lagi dalam masa pertumbuhan, sehingga dari laba di tahan yang naik dari tahun ke tahun meningkat. Di sini perusahaan masih mengunakan laba di tahan untuk meningkatkan pertumbuhan perusahaan sehingga dividen yang diberikan masih memberikan nilai yang kurang bagus.

Dilihat dari tabel indikator yang dipakai oleh perusahaan dari tahun 2013 sampai tahun 2016 mengalami penurunan, penurunan ini juga di karenakan perusahaan belum bisa menekankan biaya-biaya operasional yang tinggi dan yang menyebebakan biayabiaya operasional meningkat karena industri dalam perusahaan melakukan eksport dalam luar negeri sehingga biaya produksi mengalami kenaikan dan dalam nilai penjualannya juga ikut meningkat yang berarti dengan meningkatnya biaya-biaya maka perusahaan akan sangat sulit mendapatkan laba yang maksimal bagi perusahaan.

\section{SIMPULAN DAN SARAN}

\section{Simpulan}

Berdasarkan hasil pengolahan data, dapat dilihat bahwa perusahaan belum memenuhi harapan dari investor, karena berdasarkan dari hasil perhitungan rasio aktivitas, likuiditas, solvabilitas dalam kinerja perusahaan maka dapat disimpulkan bahwa kebijakan dividen belum masih memberikan dampak yang positif bagi perusahaan. Dalam profitabilitasnya belum menghasilkan laba yang maksimal dalam penjualannya dan harga saham perusahaan mengalami penurunan yang disebabkan karena tingkat suku bunga yang menurun, kenaikan inflasi, kondisi ekonomi sosial dan biaya-biaya yang tinggi sehingga mengalami penurunan yang negatif artinya perusahaan ini belum sesuai harapan untuk mendapatkan respon dari calon investor. 
Dividend

policy, company's growth, share performance, earning per share, share price.

\section{0}

\section{Saran}

Berdasarkan hasil simpulan diatas, maka saran-saran yang dapat diberikan adalah sebagai berikut:

a. PT Mitra Pinasthika Mustika Tbk, sebaiknya melakukan perbaikan di manajemen biaya perusahaan, agar bisa menekan biaya yang di keluarkan perusahaan dan tidak melakukan pemborosan biaya yang akan berdampak pada laba yang didapat perusahaan. Dan menarik para investor dengan dana yang ditanamkan bagi perusahaan supaya bisa mensejahterakan para investornya dengan dividen-dividen yang lebih meningkat.

b. Perusahaan harus mampu beroperasi dalam jangka panjang yang ditandai dengan tingkat laba yang memadai. Salah satu caranya yaitu selalu menjalankan strategi perusahaan yang sudah dibuat, selain itu perusahaan haruslah menjadi leader market yang bisa menguasai pasar, dengan begitu kekuatan perusahaan akan stabil dan akan bertahan dalam jangka waktu yang lama.

c. Pada penelitian selanjutnya diharapkan dapat menambahkan veriabel-variabel lainnya dalam pengaruhnya pada kebijakan dividen perusahaan.

\section{DAFTAR PUSTAKA}

Brigham Eugene F and Joe F.Houston. (2006). Dasar-Dasar Manajemen Keuangan. Alih bahasa Ali Akbar Yulianto. Buku satu. Edisi sepuluh. Jakarta: Selemba Empat.

Deitiana, T. (2009). "Faktor-Faktor yang Mempengaruhi Kebijakan Pembayaran Dividen Kas". Jurnal Bisnis dan Akuntansi. Vol. 11, No. 1. Hal. 57-64.

Fahmi, Irham. 2012. Analisis Laporan Keuangan. Alfabeta. Bandung.

Fraser, M. Lyn and Ormiston, Aileen. 2008. Understanding Finance Statements. Pearson Education. Inc. New Jersey.

Harahap, Sofyan Syafri, 2001. Budgeting Penganggaran: Perencanaan Lengkap Untuk Membantu Manajemen. Edisi Pertama, Cetakan Kedua, PT Indah Karya (Persero) Raja Grafindo Persada, Jakarta.

Husnan, Suad. (2001). Dasar-Dasar Teori Portofolio Dan Analisis Sekuritas. AMP YPKN. Yogyakarta.

Kasmir. 2008. Analisis Laporan Keuangan. PT Rajagrafindo Persada. Jakarta.

Keown, Arthur J. Et al, 2005, Financial Management : Principles and Aplications 10th Edition, New Jersey, Pearson Prentice Hall.

Michelle, dan Megawati. 2005. Memprediksi Tingkat Pengembalian Investasi Melalui Rasio Profitabilitas, Likuiditas, dan Leverage (Studi pada Perusahaan Manufaktur yang Listing di BEI Perioda Pengamatan Tahun 2001-2004). Tesis. Program Pascasarjana Universitas Airlangga Surabaya.

Prastowo, Dwi. 2007. Analisis Laporan Keuangan Konsep Dan Aplikasi. Edisi Ke-3. Yogyakarta: UPP STIM YKPN.

Riyanto, Bambang. (2008). Dasar-dasar Pembelajaran Perusahaan. Yogyakarta: Penerbit GPFE.

Ross, Stephen A., Randolph W. Westerfield, \& Bradford D. Jordan. 2009. Pengantar Keuangan Perusahaan. Jakarta: Salemba Empat.

Sangkala. 2013. Innovative Governance :Konsep dan Aplikasi. Surabaya : Capiya.

Sennahati. 2012. Analisis Likuiditas dan Profitabilitas pada PT. Graha Sarana Duta di Makassar. Jurnal Ekonomi Balance Fekon. Unismuh Makassar Vol 8-109. 
Siegel, Joel G.,Jae K. Shim. 2007. Accounting Handbook. New York: Barron's Educational

Sundjaja, R.,dan I., Barlian. 2003. Manajemen Keuangan Satu. Penerbit Linterata Lintas Media . Jakarta.

Suwardjono. 2008. Teori Akuntansi. Perekayasaan Pelaporan Keuangan.Edisi Ketiga. Yogyakarta: BPFE-Yogyakarta.

Syamsuddin, Lukman. 2008. Manajemen Keuangan Perusahaan: Konsep Aplikasi dalam: Perencanaan, Pengawasan, dan Pengambilan Keputusan. Jakarta: Rajawali Pers.

Weston, J. Fred. dan Eugene F. Brigham.1993. Manajemen Keuangan, Edisi Kesembilan. Jilid 1dan 2. Alih Bahas: Alfonsus Sirait. Erlangga, Jakarta.

Weston, J. Feed dan Thomas E. Copeland. 2010. Manajemen Keuangan. Jakarta: Binarupa Aksara.

www.idx.co.id

www.mpm-finance.com 